\title{
Suitability of reclaimed wastewater effluent from decentralized wastewater plant for irrigation
}

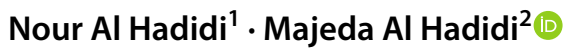

Received: 27 April 2021 / Accepted: 16 September 2021 / Published online: 15 October 2021

(C) The Author(s) 2021

\begin{abstract}
Decentralized wastewater plants have been proven to be cost-effective, easy to construct and operate and widely used in small ruler communities. The suitability of reclaimed wastewater for irrigation purpose was evaluated in this study based on the various water quality parameters, international water quality standards and water-irrigation water quality guideline (JS 1766). Twenty-seven samples were collected from a decentralized wastewater plant that is located in Balqa Governorate in Salt city, Jordan. Samples were analyzed for $\mathrm{pH}$, electrical conductivity, major anions and cations, as well as biological oxygen demand, chemical oxygen demand and total suspended solids. Study results show that water is slightly alkaline in nature. According to Jordanian domestic reclaimed wastewater standard, the use of water for irrigation has a mild-tomoderate degree of restriction. Using the US Salinity Laboratory classification scheme, there is high salinity and medium sodium water, $50 \%$ of samples falls in the area of $(\mathrm{C} 3-\mathrm{S} 2)$ and this water is suitable for irrigation for many types of soil with low risk of increasing exchangeable sodium content. According to chloride hazards, the water for irrigation can be used for moderately tolerant plants. $74 \%$ of the samples have the residual sodium carbonate (RSC) less than $1.25 \mathrm{meq} / \mathrm{L}$ and hence suitable for irrigation. The study recommends that treated wastewater from decentralized wastewater a plant is considered as non-conventional source for irrigation.
\end{abstract}

Keywords Magnesium hazard (MH) $\cdot$ Reclaimed wastewater $\cdot$ Residual sodium carbonate (RSC) $\cdot$ Sodium adsorption ratio (SAR)

\section{Introduction}

The availability of water has always been of vital importance for life. It has always played a life-sustaining role in growth and well-being of human kind. The water resources of a country constitute one of the most important economic possessions, and shortage of water resources is the most important challenges that Jordan faces, due to the presence of the semiarid climate and pollution of water sources. In addition to the mismanagement of available water resources as well as significant population growth, especially in the second

Majeda Al Hadidi

ma_hadidi@bau.edu.jo

1 Department of Vegetable and Mushroom Growing, Faculty of Horticultural Science, Szent István University, Budapest, Hungary

2 Department of Water Resources and Environmental Management, Faculty of Agriculture Technology, Al -Balqa Applied University, Al-Salt 19117, Jordan half of the twentieth century (Al-Hadidi and Al-Kharabsheh 2015). As a result of the steady increase in industrial and agricultural activities, in addition to the rapid increase in the population, this increased the demand for water resources. Jordan suffers from a scarcity of renewable water resources per capita.

It ranked second in terms of the water poverty line in 2017, with only $100 \mathrm{~m}^{3}$ per capita per year, and it is expected to decrease every year, reaching nearly 80 cubic meters in the year 2020 (MWI 2017). The experts classified countries as poor in water if the per capita water production is less than 500 cubic meters per year (MWI 2008). Current water demand in Jordan exceeds the limited renewable water resources available in the country (Saidan et al. 2020). 77\% of the total water budget in Jordan is consumed by agriculture sector according to water budget released by the ministry of water and irrigation in 2017 (MWI 2017). As agriculture consumes the bulk of the available potable water, it has become important to look for the use of substitutional sources of water for irrigation. For example, Hussain et al.

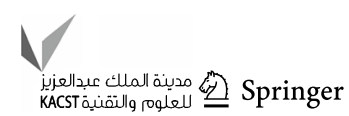


(2019) reviewed 124 recent publications on the reuse of treated wastewater also referred commonly to as reclaimed or non-potable water in agriculture and the management of non-conventional water resources. In the year 1800 , it was allowed to use reclaimed wastewater for irrigation in cities such as Paris and Boston. The use of reclaimed wastewater for irrigation was considered a solution to the problem of the large quantities of treated water leaving wastewater treatment plants (Jaramillo and Restrepo 2017).

Jordan has given top priority to the use of reclaimed wastewater in two sectors: industry and agriculture, where this water replaced freshwater, which provided additional quantities to be used for domestic purposes (Saidan et al. 2020). $0.95 \%$ of the overall quantity of reclaimed wastewater has been used for irrigation (WAJ 2008). Wastewater reuse in agriculture which is recognized as a potential source of water is extraditing a greater awareness (Alobaidy et al. 2010). Wastewater is a trustee exporter source of nutrients and organic matter and an important resource of plant nutrients (Al-Hamaiedeh and Bino 2010).

Wastewater is loaded with many organic materials, suspended solids, nutrients (mainly nitrogen and phosphorous), heavy metals, pesticides, as well as disease-causing microorganisms such as bacteria and viruses (Ungureanu et al. 2020). The use of reclaimed wastewater in irrigation has been increased in recent days due to global water scarcity, rising up the costs of fertilizers. Several studies have confirmed the importance of using reclaimed wastewater to irrigate agricultural crops because it contains many elements and nutrients that plants need, which leads to increased productivity (Maaß and Grundmann 2018).

Taking into account these facts, the research was conducted to describe the reclaimed wastewater, which is produced from decentralized wastewater treatment plant, in addition to assessing its suitability for irrigation purposes as an unconventional water resource.

Wastewater treatment plants are designed in order to reduce the environmental impact of wastewater in natural water systems. One of the main functions of wastewater treatment systems is to reduce negative impacts on the environment, which must be designed accordingly. In addition to protecting human health and surface water, other goals of wastewater treatment systems must include reducing resource losses, given the long-term needs of environmental sustainability, and minimizing energy and water use (Jajac et al. 2019).

Essentially, decentralized sewer networks have less buffering capacity retention time and subsequently the design process must be adequate durable to control the extensive wide difference of influent flows and qualities. Decentralized wastewater management is used to treat and dispose, at or near the source, relatively small volumes of wastewater, originating from single households or groups of dwellings located in relatively close and not served by a central sewer system connecting them to a regional wastewater treatment plant (Capodaglio 2017). The decentralized approach for treatment of municipal wastewater is useful, for a number of reasons; the most important is cost-efficient treatment planning for rural communities with scattered populations, and it permits householder to continue the use of sewer systems fairly and protective management of wastewater. The conventional onsite system can be defined as a natural or mechanistic system, which collects, treat, discharge or recover wastewater from a residence with a limited number of people without the need for sanitation networks and uses it at the local level or resort to a central treatment facility. The traditional onsite system contains a septic tank and a drain field. Other types of substitute's alternate onsite systems include heap systems, media filters, small aerobic units and pressure distribution systems which includes a septic tank and a drain field (Sharma et al. 2012).

The classification of the United States Salinity Laboratory Staff (USSLS 1954) diagram is used most commonly to estimate the appropriateness of water for irrigation purposes. Parameters like electrical conductivity (EC), pH, total nitrogen, residual sodium carbonate (RSC), soluble sodium percentage (SSP), sodium adsorption ratio (SAR) and exchangeable sodium percentage (ESP) were used. Water fineness criterion can be used as a proof to help farmers to choose the appropriate agricultural practices to overcome the risk of salinity (Wilcox 1948). Table 1 provides values for the suitability of water for use as a general guide in order to explain the suitability of water for irrigation based on the degree of restriction as well as the classification of this water for irrigation.

The aim of the study was to assess the suitability of reclaimed wastewater plants for irrigation, based on the various water quality parameters, international water quality standards and Jordanian reclaimed domestic wastewater standard.

\section{Materials and methods}

\section{Site description}

The plant of decentralized wastewater is situated in Balqa Governorate in Salt city, and it lies in the center of Jordan, $25 \mathrm{~km}$ north of the capital city of Amman. Geographical coordinates are $32^{\circ} 2^{\prime} 21^{\prime \prime}$ North, $35^{\circ} 43^{\prime}$ $38^{\prime \prime}$ East Balqa Governorate covers an area of $1120 \mathrm{~km}^{2}$ with an altitude of $820 \mathrm{~m}$ above the sea level. The study area is characterized by a dry to semiarid climate with cold winters to hot summers. The yearly average maximum temperature is $21.4{ }^{\circ} \mathrm{C}$ and a minimum of $12.7^{\circ} \mathrm{C}$, and the yearly total rainfall is $586 \mathrm{~mm}$ (MWI 2019). The 
Table 1 Water quality classes for agricultural irrigation (Ayers and Wesstcott 1985), (USSLS 1954)

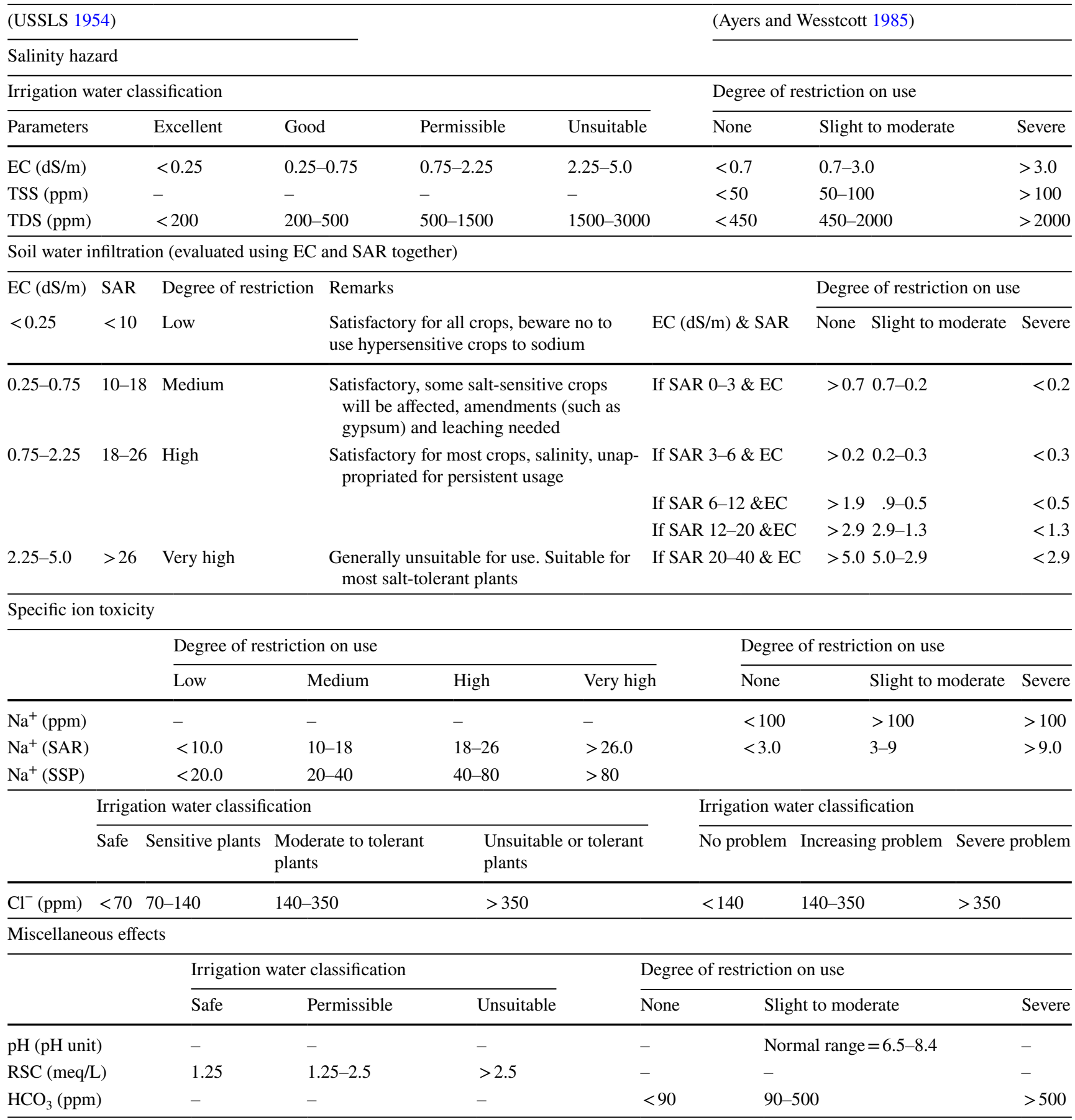

decentralized plant is composed of septic tank and horizontal flow wetland filter of $7 \mathrm{~m}$ by $5 \mathrm{~m}$ full of crushed gravel of $1 \mathrm{~cm}$ in diameter. In Fig. 1, a schematic diagram shows the configuration of the decentralized wastewater treatment plant.

\section{Sampling and analysis}

Samples from decentralized wastewater plant located in Salt and samples from tap water were collected twice monthly. Polyethylene bottles are prewashed with diluted 
Fig. 1 A schematic diagram shows the configuration of the decentralized wastewater treatment plant

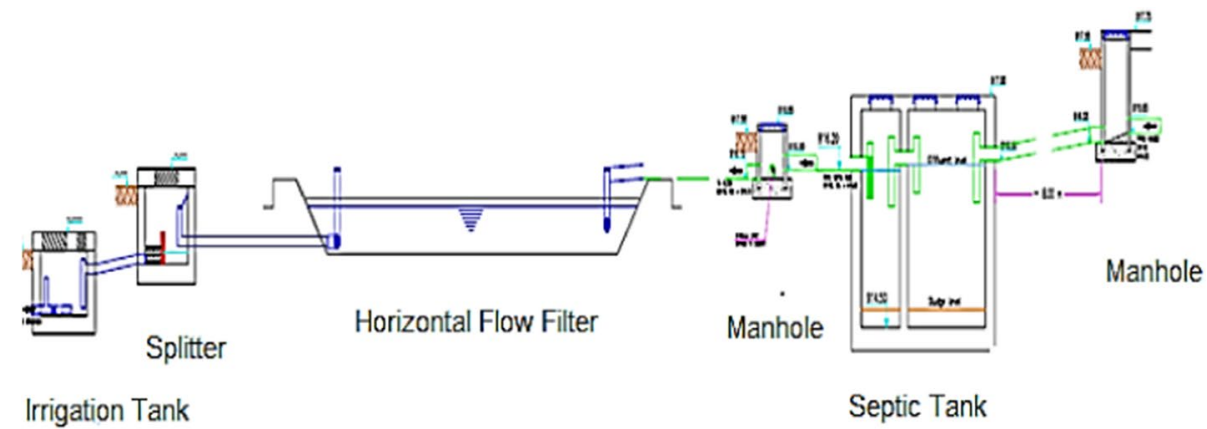

hydrochloric acid and rinsed several times with the effluent sample before filling them to the required volume. These samples were stored at a temperature below $4{ }^{\circ} \mathrm{C}$ before being analyzed in the laboratory. Steps followed for analysis are according to the standard methods for examination of water and wastewater (APHA 2017).

Samples were analyzed for sixteen parameters including, $\mathrm{pH}$, electrical conductivity (EC), total hardness calcium $\left(\mathrm{Ca}^{2+}\right)$, magnesium $\left(\mathrm{Mg}^{2+}\right)$, sodium $\left(\mathrm{Na}^{+}\right)$, potassium $\left(\mathrm{K}^{+}\right)$, bicarbonate $\left(\mathrm{HCO}_{3}{ }^{-)}\right.$, carbonate $\left(\mathrm{CO}_{3}{ }^{2-}\right)$, chloride $\left(\mathrm{Cl}^{-}\right)$, nitrate $\left(\mathrm{NO}_{3}{ }^{-}\right)$, total nitrogen $(\mathrm{TN})$ and phosphate $\left(\mathrm{PO}_{4}{ }^{3-}\right)$, in addition to chemical oxygen demand (COD), biological oxygen demand (BOD) and total suspended solids (T.S.S). The analytical methods were executed according to standard method for the examination of water and wastewater (APHA 2017). Table 2 summarizes the analytical method for the analyzed parameters.

\section{Result and discussion}

The suitability of using reclaimed water for irrigation is subject to the effect of its mineral components on both the plant and the soil (Todd 1980). The validity of all kinds of water for irrigation includes a numbers of qualitative characteristics of water, with respect to the crop and its quality (Hussain and Al-Saati 1999). In addition to maintaining soil productivity and environmental preservation, these parameters mainly control some of the chemical and physical properties of the water used to assess agricultural water quality. Many guidelines for water quality have been promoted in order to be used for irrigation (Ayers 1985).

\section{Quality of raw water}

Raw water which enters the decentralized unit is a black water which is defined as any wastewater that has come into contact with human waste (Brtalik et al. 2012). Water entering the unit comes from a residential house of a population
Table 2 Analytical methods used to determine various parameters (APHA 2017)

\begin{tabular}{lll}
\hline Parameter & Analytical methods, used & Method No. \\
\hline Acidity (pH) & Electrometric method & $4500 \mathrm{~B} / \mathrm{H}^{+}$ \\
Electrical conductivity (EC) & Conductivity & 2510 \\
Total hardness (T.H) & EDTA titrimetric method & $2340 \mathrm{C}$ \\
Calcium $\left(\mathrm{Ca}^{2+}\right)$ & EDTA titrimetric method & $3500 \mathrm{D} / \mathrm{Ca}$ \\
Magnesium $\left(\mathrm{Mg}^{2+}\right)$ & EDTA titrimetric method & $3500 \mathrm{E} / \mathrm{Mg}$ \\
Sodium $\left(\mathrm{Na}^{+}\right)$ & Flame emission photometric method & $3500 \mathrm{D} / \mathrm{Na}$ \\
Potassium $\left(\mathrm{K}^{+}\right)$ & Flame emission photometric method & $3500 \mathrm{D} / \mathrm{K}$ \\
Bicarbonate $\left(\mathrm{HCO}_{3}{ }^{-}\right)$ & Titrimetric method & $2320 \mathrm{~B}$ \\
Carbonate $\left(\mathrm{CO}_{3}{ }^{2-}\right)$ & Titrimetric method & $2320 \mathrm{~B}$ \\
Chloride $\left(\mathrm{Cl}^{-}\right)$ & Argentometric method & $4500 \mathrm{~B} / \mathrm{Cl}$ \\
Nitrate $\left(\mathrm{NO}_{3}{ }^{-}\right)$ & Spectrophotometer (ultraviolet spectrophotometer & $4500 \mathrm{~B} / \mathrm{NO}{ }^{-1}$ \\
& screening method) & \\
Phosphate $\mathrm{PO}_{4}{ }^{3-}$ & Stannous chloride method & $4500-\mathrm{P} \mathrm{D}$ \\
TSS & Total suspended solids dried at 103-105 ${ }^{\circ} \mathrm{C}$ & $2540 \mathrm{D}$ \\
BOD & 5 -day BOD test & $5210 \mathrm{~B}$ \\
COD & Closed reflux, titrimetric method & $5220 \mathrm{C}$ \\
\hline
\end{tabular}


Table 3 Average values of physical and chemical parameters of raw wastewater

\begin{tabular}{ll}
\hline Characteristics & Average \\
\hline $\mathrm{pH}$ & 7.2 \\
$\mathrm{EC}(\mu \mathrm{s} / \mathrm{cm})$ & 1837 \\
$\mathrm{Ca}^{2+}(\mathrm{mg} / \mathrm{l})$ & 65 \\
$\mathrm{Mg}^{2+}(\mathrm{mg} / \mathrm{l})$ & 30.0 \\
$\mathrm{TH}(\mathrm{mg} / \mathrm{l})$ & 274 \\
$\mathrm{HCO}_{3}{ }^{-}(\mathrm{mg} / \mathrm{l})$ & 314 \\
$\mathrm{Cl}^{-}(\mathrm{mg} / \mathrm{l})$ & 156 \\
$\mathrm{Na}^{+}(\mathrm{mg} / \mathrm{l})$ & 232 \\
$\mathrm{~K}^{+}(\mathrm{mg} / \mathrm{l})$ & 32 \\
$\mathrm{PO}_{4}{ }^{3-}(\mathrm{mg} / \mathrm{l})$ & 24.0 \\
$\mathrm{NO}_{3}{ }^{-}(\mathrm{mg} / \mathrm{l})$ & 82 \\
$\mathrm{BOD}^{(\mathrm{mg} / \mathrm{l})}$ & 767 \\
$\mathrm{COD}(\mathrm{mg} / \mathrm{l})$ & 1217 \\
$\mathrm{TSS}(\mathrm{mg} / \mathrm{l})$ & 1477 \\
\hline
\end{tabular}

of twelve people. Activities, which are practiced, are a daily activity of cleaning, kitchen sinks, dishwashers and bathrooms water. There is no industrial source of water. Mean values of physical and chemical characteristics of raw wastewater are reported in Table 3. Olive and lemon trees were irrigated by reclaimed wastewater using subsurface irrigation; this irrigation system is used to control the depth of an existing water table.
Irrigation water is provided where it reaches the root zone, taking into account the minimum level of contact with the human element in addition to the leaves of the tree; because of these reasons, it has been found that the subsurface irrigation system is best suited for irrigation of crops with reclaimed wastewaters. Cribriform tube (Bi-wall) or dripping laterals with slits and orifices or emitters are placed below ground surface in the root zone. The emitters are placed at sufficient depth so that the crop absorbs the water highly efficiently. The proper management of the irrigation process leads to the control of deep filtration that occurs outside the root, in addition to reducing the loss of evaporation to a minimum.

Physical and chemical parameters of reclaimed wastewater and tap water were statistically analyzed using excel, including statistical measures, such as minimum, maximum, mean and standard deviation, which are reported in Table 4.

Suitability of reclaimed wastewater quality for irrigation purpose was assessed according to water-irrigation water quality guideline (JS 1766, 2014) in Table 5.

\section{Hydrogen ion activity (pH)}

The samples are alkaline in nature with a minimum of 7.2 and a maximum of 8.3 and a mean of 7.7. The prevalent $\mathrm{pH}$ range for irrigation water is from 6.5 to 8.4. The irrigation
Table 4 Minimum, maximum and mean values of physical and chemical parameters of reclaimed wastewater and tap water with statistical parameters

\begin{tabular}{|c|c|c|c|c|c|c|c|c|}
\hline \multicolumn{5}{|l|}{ Treated wastewater } & \multicolumn{4}{|c|}{ Tab water } \\
\hline Characteristics & Min. & Max. & Mean. & Standard deviation & Min. & Max. & Mean. & Standard deviation \\
\hline $\mathrm{pH}$ & 7.2 & 8.3 & 7.7 & \pm 0.2 & 7.3 & 8.3 & 8.1 & \pm 0.3 \\
\hline $\mathrm{EC}(\mu \mathrm{s} / \mathrm{cm})$ & 781 & 2810 & 1801.7 & \pm 406.2 & 485 & 987 & 828 & \pm 125.4 \\
\hline $\mathrm{Ca}^{2+}(\mathrm{mg} / \mathrm{l})$ & 56.0 & 99.2 & 72.7 & \pm 11.6 & 68.8 & 100.8 & 80.6 & \pm 9.0 \\
\hline $\mathrm{Mg}^{2+}(\mathrm{mg} / \mathrm{l})$ & 14.5 & 50.2 & 33.15 & \pm 10.6 & 13.1 & 34.7 & 20.1 & \pm 6.5 \\
\hline $\mathrm{TH}(\mathrm{mg} / \mathrm{l})$ & 240 & 398 & 318.7 & \pm 45.2 & 238 & 328 & 286.1 & \pm 18.4 \\
\hline $\mathrm{HCO}_{3}^{-}(\mathrm{mg} / \mathrm{l})$ & 222 & 383.1 & 339.6 & \pm 29.9 & 97.6 & 168 & 115.5 & \pm 12.7 \\
\hline $\mathrm{CO}_{3}^{2-}(\mathrm{mg} / \mathrm{l})$ & 0.0 & 0.0 & 0.0 & \pm 0.0 & 0.0 & 0.0 & 0.0 & \pm 0.0 \\
\hline $\mathrm{Cl}^{-}(\mathrm{mg} / \mathrm{l})$ & 20.3 & 373.9 & 247.4 & \pm 115.9 & 108 & 208 & 159.9 & \pm 29.3 \\
\hline $\mathrm{Na}^{+}(\mathrm{mg} / \mathrm{l})$ & 130 & 418.4 & 251.1 & \pm 80.77 & 37.9 & 202.7 & 120.0 & \pm 35.4 \\
\hline $\mathrm{K}^{+}(\mathrm{mg} / \mathrm{l})$ & 7.6 & 59.6 & 28.6 & \pm 12.3 & 1.8 & 9.3 & 5.7 & \pm 1.8 \\
\hline $\mathrm{PO}_{4}{ }^{3-}(\mathrm{mg} / \mathrm{l})$ & 2.4 & 27.1 & 16.4 & \pm 7.4 & 0 & 0.4 & 0.0 & \pm 0.1 \\
\hline T-N (mg/l) & 42.9 & 81.6 & 55.4 & \pm 15.6 & - & - & - & - \\
\hline $\mathrm{NO}_{3}^{-}(\mathrm{mg} / \mathrm{l})$ & 5.4 & 44.5 & 29.1 & \pm 12.9 & 8.3 & 44.0 & 17.2 & \pm 7.7 \\
\hline BOD (mg/l) & 34.0 & 246 & 101.9 & \pm 60.9 & - & - & - & - \\
\hline $\mathrm{COD}(\mathrm{mg} / \mathrm{l})$ & 98.0 & 360 & 217.5 & \pm 60.0 & - & - & - & - \\
\hline TSS (mg/l) & 13.3 & 95 & 45.58 & \pm 25.51 & 1 & 3.2 & 1.6 & \pm 0.7 \\
\hline SAR & 3.0 & 12.9 & 6.7 & \pm 2.2 & 1.1 & 5.5 & 3.2 & \pm 0.9 \\
\hline $\mathrm{Na} \%$ & 43.7 & 75.3 & 63.4 & \pm 7.8 & 26.1 & 62.6 & 47.3 & \pm 7.7 \\
\hline $\mathrm{SSP} \%$ & 42.3 & 71.9 & 59.3 & \pm 7.6 & 23.8 & 61.7 & 46.0 & \pm 8.1 \\
\hline $\mathrm{ESP} \%$ & 3.1 & 15.1 & 7.8 & \pm 2.7 & 0.41 & 6.4 & 3.3 & \pm 1.2 \\
\hline RSC (meq/l) & -1.5 & 2.1 & 0.4 & \pm 1.0 & -4.4 & -1.8 & -3.4 & \pm 0.5 \\
\hline Mg hazards (meq/l) & 21.5 & 57.6 & 42.5 & \pm 9.9 & 19.2 & 45.2 & 29.1 & \pm 8.3 \\
\hline
\end{tabular}


Table 5 water-irrigation water quality guideline (JS 1766, 2014)

\begin{tabular}{|c|c|c|c|c|c|}
\hline \multirow[t]{2}{*}{ Parameters } & \multirow[t]{2}{*}{ unit } & \multicolumn{3}{|c|}{ Degree of restriction on use } & \multirow[t]{2}{*}{ Sample range } \\
\hline & & None & Slight to moderate & Severe & \\
\hline $\mathrm{pH}$ & & Normal range (6-9) & & & $7.19-8.27$ \\
\hline EC & $\mathrm{dS} / \mathrm{m}$ & $>1.7$ & $1.7-3.0$ & $<3$ & $0.78-2.8$ \\
\hline TSS & $\mathrm{mg} / \mathrm{L}$ & $>50$ & $50-100$ & $<100$ & $13.3-95$ \\
\hline TDS & $\mathrm{mg} / \mathrm{L}$ & $>1088$ & $1088-2000$ & $<2000$ & $500-2000$ \\
\hline $\mathrm{BOD}_{5}$ & $\mathrm{mg} / \mathrm{L}$ & $>60$ & $110-400$ & $<400$ & $34-246$ \\
\hline COD & $\mathrm{mg} / \mathrm{L}$ & $>120$ & $250-1000$ & $<1000$ & $98-360$ \\
\hline $\mathrm{HCO}_{3}^{-}$ & $\mathrm{mg} / \mathrm{L}$ & $>90$ & $90-520$ & $<520$ & $222-383$ \\
\hline $\mathrm{Ca}^{2+}$ & $\mathrm{mg} / \mathrm{L}$ & 230 & 230 & 230 & $56-99.2$ \\
\hline $\mathrm{Mg}^{2+}$ & $\mathrm{mg} / \mathrm{L}$ & 100 & 100 & 100 & $14.47-50.2$ \\
\hline \multicolumn{6}{|l|}{ SAR } \\
\hline $0-3$ & & $\mathrm{EC}<0.7$ & EC $0.2-0.7$ & $\mathrm{EC}>0.2$ & \\
\hline $3-6$ & & $\mathrm{EC}<1.2$ & EC $0.3-1.2$ & $\mathrm{EC}>0.3$ & \\
\hline $6-12$ & & $\mathrm{EC}<1.9$ & EC $0.5-1.9$ & $\mathrm{EC}>0.5$ & \\
\hline $12-20$ & & $\mathrm{EC}<2.9$ & EC $1.3-2.9$ & $\mathrm{EC}>1.3$ & $3.01-12.93$ \\
\hline $20-40$ & & $\mathrm{EC}<5$ & EC $2.9-5$ & $\mathrm{EC}>2.9$ & \\
\hline $\mathrm{Na}^{+}$ & $\mathrm{mg} / \mathrm{L}$ & $<69$ & 69-207 & $>207$ & $130-418.2$ \\
\hline $\mathrm{N}-\mathrm{NO}_{3}{ }^{-}$ & $\mathrm{mg} / \mathrm{L}$ & $<5$ & $5-30$ & $>30$ & $5.41-44.54$ \\
\hline T-P & $\mathrm{mg} / \mathrm{L}$ & $<6$ & $6-20$ & $>20$ & - \\
\hline $\mathrm{Cl}^{-}$ & $\mathrm{mg} / \mathrm{L}$ & $<142$ & $142-355$ & $>355$ & $20.29-373.9$ \\
\hline B & $\mathrm{mg} / \mathrm{L}$ & $<0.7$ & $0.7-3$ & $>3$ & - \\
\hline $\mathrm{Fe}^{2+}$ & $\mathrm{mg} / \mathrm{L}$ & $<0.1$ & $0.1-1.5$ & $>1.5$ & - \\
\hline $\mathrm{Mn}^{2+}$ & $\mathrm{mg} / \mathrm{L}$ & $<0.1$ & $0.1-1.5$ & $>1.5$ & - \\
\hline
\end{tabular}

with higher $\mathrm{pH}$ water than the allowable limit will lead to nutritional imbalance; in addition, it may contain toxic material (USSLS 1954). According to water-irrigation water quality guideline (JS 1766, 2014), all samples are within the normal range of $\mathrm{pH}$. $\mathrm{pH}$ higher than 8.5 is predominating caused by high concentrations of carbonate $\left(\mathrm{CO}_{3}{ }^{2-}\right)$ and bicarbonate $\left(\mathrm{HCO}_{3}{ }^{-}\right)$.

Insoluble minerals of calcium and magnesium ions are formed under high concentration of carbonates leaving sodium as the prevalent in solution. This alkaline water could concentrate intensify sodic soil situation (Khodapanah et al. 2009).

\section{Salinity hazard}

The electrical conductivity is an important factor in determining the suitability of treated municipal wastewater for irrigation purposes, because it is a good measure of the risk of salinity for the yield and productivity of crops, as it explains the total dissolved solids (TDS) in municipal wastewater (Alobaidy et al. 2010). Irrigation with reclaimed wastewater has a major negative effect, which is the increase in soil salinity. If the increase in soil salinity resulting from irrigation with reclaimed wastewater is not controlled, it will lead to a decrease in crop productivity in the long run (Ayers 1985). The main effect of high (EC) water on the yield is inhabitation of the plant to compete with ions in the soil solution for water (physiological drought) (Bauder et al. 2010).

EC values of experimental samples changed from 781 to $2810 \mu \mathrm{S} / \mathrm{cm}$ (mean value $=1801.7 \mu \mathrm{S} / \mathrm{cm}$ ). According to water-irrigation water quality guideline (JS 1766, 2014), the wastewater use for irrigation is slight-to-moderate degree of constrains due to accumulation of salt in soils and its harmful effects on plant. It can be concluded that this water can be used in soil with limited drainage. Salinity monitoring management is required especially for salinity control with a choice of a group of plants that is salt-tolerant. According to (Shakir et al. 2017), using reclaimed municipal wastewater with conductivity in the range of $750-2250 \mu \mathrm{S} / \mathrm{cm}$ is allowable for irrigation and excessively used.

The productivity is gained favorable under perfect management and a suitable drainage condition. It is evident that the use of reclaimed municipal wastewater for irrigation increases the concentration of salts, which may lead to crop damage. It is therefore essential to integrate between reclaimed municipal wastewater reuse and the use of agricultural practices that control salinity like leaching process and appropriate drainage (Subramani et al. 2005). 


\section{Sodium hazard}

Knowing the water content of the sodium is one of the substantial factors worthy in assessing evaluation the quality of water for irrigation. Surplus sodium concentration leads to development of alkaline soil, which causes problems in the soil in addition to reducing soil permeability (Bouwer and Idelovitch 1987). Because excess sodium salts can be absorbed directly through the leaves of the plant and thus accumulate and deterioration of crop productivity.

The irrigation water quality guideline (JS 1766, 2014) indicates a slight to moderate restriction of using reclaimed municipal wastewater water with sodium concentration between (69-207 mg/L), indicating slight to moderate restriction of use. Sodium concentrations in the samples ranged from 130 to $418 \mathrm{mg} / \mathrm{L}$ (mean value $=251 \mathrm{mg} / \mathrm{L}$ ), indicating slight-to-moderate high degree of restriction for sensitive crops on the use of this wastewater in irrigation (Ayers 1985). Sodium adsorption ratio (SAR) is an important parameter for determining the suitability of groundwater for irrigation because it is a measure of alkali/sodium hazard to crops. This index quantifies the extent of sodium to calcium and magnesium ions in a sample. Immoderate sodium content close to the calcium and magnesium reduces the soil permeability and thus prevents the supply of water needed for the crops (UCCC 1974). SAR is calculated by Eq. 1 (Richards 1954), where the concentrations of all ions are in milliequivalents per liter (meq/l):

$\mathrm{SAR}=\frac{\mathrm{Na}^{+}}{\sqrt{\frac{\mathrm{Ca}^{+2}+\mathrm{Mg}^{+2}}{2}}}$

The SAR amount of the reclaimed municipal wastewater ranges from 3 to 13 (mean $=6.7)$. According to water-irrigation water quality guideline (JS 1766, 2014), using reclaimed municipal wastewater water with SAR (3-13) shows severe restriction of use. A more detailed analysis for the suitability of water for irrigation was performed by plotting the data on US Salinity Laboratory Diagram. The suitability of reclaimed wastewater for irrigation has been identified through the use of US Salinity Laboratory Diagram (USSL 1954). In this consideration, the US salinity diagram (Fig. 2), which is based on the incorporated effect of electrical conductivity (salinity hazard) and sodium adsorption ratio (alkalinity hazard), has been used to evaluate the water appropriateness for irrigation.

The analytical data plotted on the US salinity diagram illustrate that $50 \%$ of the reclaimed wastewater samples fall in the field (C3-S2), and it indicates high water salinity and medium sodium content that can be used for irrigation for almost all types of soil with little risk of sodium

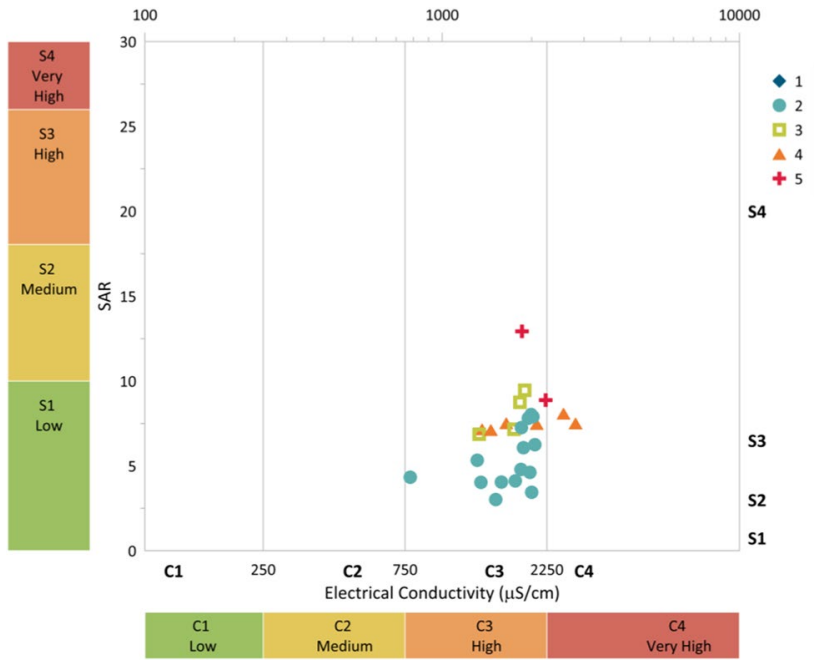

Fig. 2 US salinity diagram for reclaimed wastewater

Table 6 Correlation matrix between reclaimed wastewater and tap sample (SAR)

\begin{tabular}{llllll}
\hline Characteristics & \multicolumn{5}{l}{ Reclaimed wastewater } \\
\cline { 2 - 6 } & SAR & Na\% & SSP & ESP & EC \\
\hline Tab water & & & & & \\
SAR & 0.38820 & 0.27776 & 0.34702 & 0.38038 & 0.11748 \\
& 0.0454 & 0.1607 & 0.0762 & 0.0503 & 0.5595 \\
Na\% & 0.25919 & 0.20744 & 0.27498 & 0.25601 & 0.11130 \\
& 0.1917 & 0.2992 & 0.1651 & 0.1974 & 0.5805 \\
SSP & 0.27802 & 0.22743 & 0.29666 & 0.27521 & 0.11359 \\
& 0.1603 & 0.2539 & 0.1329 & 0.1647 & 0.5727 \\
ESP & 0.39067 & 0.27660 & 0.34781 & 0.38276 & 0.11600 \\
& 0.0439 & 0.1625 & 0.0754 & 0.0488 & 0.5645 \\
EC & 0.33493 & 0.38616 & 0.35667 & 0.34604 & 0.32707 \\
& 0.0877 & 0.0466 & 0.0678 & 0.0771 & 0.0959 \\
\hline
\end{tabular}

substitution (Fig. 2). This type of water is suitable for plants that have tolerance to salinity, especially in soils with limited drainage (Karanth 1989). Table 6 shows the positive correlation between electrical conductivity and sodium adsorption ratio with a correlation coefficient $\left(R^{2}\right)=0.5595$. The higher values of $R^{2}$ show that there is a lower variation in the electrical conductivity values. High values of soil salinity and SAR cause soil structure deteriorations, decrease in soil permeability and reduction of crop yields due to toxic and osmotic effects (Halliwell et al. 2001).

When the SAR and soil salinity are high, clay soils may swell and individual clay particles disperse from soil aggregates when they are wetted. This causes soil aggregates to collapse, and the tiny clay particles then block soil pores. On drying, the soil becomes dense and with a

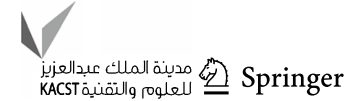


poor structure. Sodicity can dramatically lead to reduce soil water movement and accumulation of salts and other toxic elements (Rengasamy et al. 2010).

\section{Soluble sodium percentage (SSP)}

Soluble sodium percentage (SSP) is also used to estimate sodium hazard. It is defined as the ratio of soluble sodium concentration to the total cations concentration, and irrigated water with SSP greater than $60 \%$ will cause collapse in the physical properties of soil (Fipps 1998). Soluble sodium percentage (SSP) is calculated using Eq. 2 given by (Todd 1995):

$\mathrm{SSP}=\frac{\mathrm{Na}^{+}}{\mathrm{Ca}^{+2}+\mathrm{Mg}^{+2}+\mathrm{Na}^{+}+\mathrm{K}^{+}} \times 100$

where all the ionic concentrations are expressed in milliequivalents per liter (meq/l). The calculated amount of SSP varied from 42.3 to $71.9 \%$ (mean value $=59.3 \%$ ) indicating high degree of restriction on the use of this wastewater in irrigation. When the concentration of sodium ion is high in irrigation water, the sodium ion tends to be absorbed by clay particles, replacing divalent cations magnesium and calcium. The continuous use of water with alkaline properties in irrigation will affect the physical properties of the soil, in addition to reducing the permeability of the soil as a result of the ion exchange process, and ultimately leads to the presence of soil with poor drainage (Halliwell et al. 2001). Irrigation with water high in salinity and sodium concentration is the principle water quality interest in areas irrigated with this water. In areas with restricted limited rainfall and high evaporation, soil sodicity may safely increase.

\section{Percent sodium (\% $\mathrm{Na})$}

The percent sodium (\% Na) is defined as (Eq. 3):

$\% \mathrm{Na}=\frac{(\mathrm{Na}+\mathrm{K})}{(\mathrm{Ca}+\mathrm{Mg}+\mathrm{Na}+\mathrm{K})} \times 100$

All ionic concentrations are estimated in milliequivalents per liter (meq/l). The classifications given by (Wilcox 1948) display that $90 \%$ of water samples falls in permissible categories indicating their suitability for irrigation. When a high concentration of sodium occurs in the irrigation water, clay soil particles tend to absorb sodium ions instead of $\mathrm{Mg}^{2+}$ and $\mathrm{Ca}^{2+}$ ions (Al-Khashman et al. 2013). This ion exchange process leads to reduce soil permeability and drainage. Hence, during this humid condition air, water circulation becomes restricted and soil becomes hard when it is dried (Collins and Jenkins 1996).

\section{Exchangeable sodium percentage (ESP)}

$10-15 \%$ of the ESP is accepted as a critical level, as it is a good indicator of the deterioration of soil structure, and a critical level of $10-15 \%$ ESP is generally accepted. An ESP of 5\% is considered high in soils consisting of 2:1 clay minerals such as montmorillonite, whereas an ESP of $25 \%$ may have negligible effect on soil structure in a sandy soil (Van Hoorn and Van Alpen 1990). Using the following empirical relationship (Eq. 4), the ESP of soils can be predicted:

$\mathrm{ESP}=\frac{100(-0.0126+0.1475 \mathrm{SAR})}{1+(-0.0126+0.01475 \mathrm{SAR})}$

The potential ESP for the experimental data is in range of 3.08-15.11 $($ mean $=7.81)$ as shown in Table 6

\section{Chloride hazard}

Chloride can cause toxicity to sensitive crops at high concentrations even it is essential to plants in very low amounts (Ayers 1985). Especially when used in sprinkler irrigation system (Bauder et al. 2010). The most common source of toxicity for chloride in the soil is that it moves easily with the soil water, and thus, the plants take it and accumulate in the leaves. Drying of leaves tissue is developed when the chloride concentration is higher than the tolerance of the crop. The chloride ion concentration ranged from 20.3 to $373.9 \mathrm{mg} / \mathrm{L}$ (mean value $=247.4$ ), whereas, according to USSL classification of irrigation water, the effluent samples can be used in plants with moderate tolerance (USSL 1954).

\section{Residual sodium carbonate (RSC)}

The residual sodium carbonate explains the excess sum of carbonate and bicarbonate over the sum of calcium and magnesium, which affect the inadequacy of wastewater for irrigation (Eaton 1950). In water having high concentration of carbonate and bicarbonate, the concentration of carbonates is in excess of the concentration of alkaline earths. The excess carbonates combine with sodium to form sodium carbonate, which affects the soil structure (Bhuriya and Dev 2014).

Therefore, a relationship between the concentration of alkaline earth and carbonates can be used to explain the suitability of water for irrigation. The RSC is calculated by subtracting the amount of calcium and magnesium concentration from the amount of carbonates, as shown in Eq. 5 (Karanth 1987): 
$\mathrm{RSC}=\left(\mathrm{CO}_{3+} \mathrm{HCO}_{3}-(\mathrm{Ca}+\mathrm{Mg})\right.$

All ionic concentrations are expressed in milliequivalents per liter. Land irrigated by water with high RSC has high $\mathrm{pH}$, so the soil becomes infertile, and black color of the soil occurs due to deposition of sodium carbonate (Ayers and Tanji 1999). If the residual sodium carbonate is less than $1.3 \mathrm{meq} / \mathrm{L}$, the water can be classified as suitable, permissible suitable, if the residual sodium carbonate is between 1.3 and $2.5 \mathrm{meq} / \mathrm{L}$; and unsuitable for irrigation, if the residual sodium carbonate is more than $2.5 \mathrm{meq} / \mathrm{L}$. The higher residual sodium carbonate leads to increase in adsorption of sodium in soil, which reduces the soil permeability, supporting the plant growth. The value of residual sodium carbonate is between 1.5 and $2.0 \mathrm{meq} / \mathrm{L}$ in the present study. Approximately $74 \%$ of the samples have the residual sodium carbonate less than $1.3 \mathrm{meq} / \mathrm{L}$ and hence suitable for irrigation.

\section{Magnesium hazard}

In most water, calcium and magnesium preserve a state of equilibrium (Prasanth et al. 2012). Ratio index was developed by Paliwal (1972). According to this ratio index, high magnesium hazard value has an opposite effect on the crop productivity as the soil becomes more alkaline. Magnesium hazard was calculated according to Eq. 6 given by (Szabolcs and Darab 1964), where the concentration of each cation was expressed in meq/L.

$\mathrm{Mg}$ Hazard $=\frac{\mathrm{Mg}}{\mathrm{Mg}+\mathrm{Ca}} \times 100$

Calcium and magnesium ions are expressed in milliequivalents per liter $(\mathrm{meq} / \mathrm{L})$. The magnesium hazard values fall in the range of $21.5-57.6 \%($ mean $=42.5)$, and the reclaimed wastewater can be classified with few exceptions as suitable for irrigation use. $74 \%$ of the samples collected showed magnesium hazard ratio below 50\% (suitable for irrigation), while $26 \%$ falls in the unsuitable category with magnesium hazard above $50 \%$. The evaluation illustrates that $26 \%$ of samples can cause negative effect on the agricultural production.

\section{Total nitrogen}

The nutrient in reclaimed wastewater provides amounts of fertilizer for crops. However, in certain instances, the increase leads to uneven maturity of the crop, low quality in addition to excessive vegetative growth (Asano and Pettygrove 1987). One of the most nutrients occurring in reclaimed wastewater in significant quantities is nitrogen. Idealistic wastewater typically contains $33 \mathrm{mg} / \mathrm{L}$ of total nitrogen, most of this is in the ammonium $\left(\mathrm{NH}_{4}\right)$ form, and with little present as nitrate, reclaimed wastewater contains at least the total crop requirement for nitrogen. The calculated values of $T-N$ ranged from 42.9 to $81.6 \mathrm{mg} / \mathrm{l}$ (mean value $=55.4$ ); according to water-irrigation water quality guideline (JS 1766, 2014), the use of this wastewater in irrigation indicates high degree of restriction.

\section{Other related characteristics}

The possible sources of oxygen demand in reclaimed wastewater are the biochemical degradation of organic materials, oxidation of inorganic material and the oxidation of nitrogen (WHO 2005). The total suspended solids, chemical oxygen demand and biochemical oxygen demand values in the present study ranged from 13.3 to $95 \mathrm{mg} / \mathrm{L}, 98$ to $360 \mathrm{mg} / \mathrm{L}$ and 34 to $246 \mathrm{mg} / \mathrm{L}$, respectively. The results highlight that the effluent from decentralized wastewater treatment plant meets water-irrigation water quality guideline (JS 1766, 2014).

\section{Environmental aspects associated with wastewater use for irrigation}

Improvement of the environment could be achieved when reclaimed wastewater is used properly for agricultural purposes than being disposed in any other way. Some environmental benefits are achieved by using reclaimed wastewater for irrigation and prohibition appearance of unpleasant esthetic situations (Pipeline 2000). Provision of groundwater resources prevents soil erosion and soil conservation, reduces the humus accumulated on agricultural land and allows homeowners to use their septic systems properly.

\section{Conclusions and recommendations}

The water quality of the effluent of decentralized wastewater goes with the water-irrigation water quality guideline (JS 1766, 2014). According to water-irrigation water quality guideline (JS 1766, 2014), the water has a slight-to-moderate degree of restriction to use in irrigation. Interpretation of physical and chemical analysis indicates that the quality of the effluent of decentralized wastewater plant is slightly alkaline in nature. Wilcox and US Laboratory Salinity Staff diagrams reveal that $50 \%$ of samples fall in the area of (C3S2). So this water is suitable for irrigation for many types with low risk of increasing exchangeable sodium content.

According to chloride hazards, the irrigation water of the effluent samples can be used for moderately tolerant plants. Approximately $74 \%$ of the samples have the residual sodium carbonate (RSC) less than $1.25 \mathrm{meq} / \mathrm{L}$ and hence suitable for irrigation. In the study area, $74 \%$ of the samples collected showed magnesium hazard ratio below $50 \%$ (suitable for 
irrigation), while $26 \%$ falls in the unsuitable category with magnesium hazard above $50 \%$. The study recommends that treated wastewater from decentralized wastewater plant is considered as non-conventional source for irrigation.

\section{Recommendations}

It is essential to have compatible management of wastewater irrigation and frequent monitoring of quality parameters, in order to have safe and long-term reuse of wastewater for irrigation, It is recommended that reclaimed wastewater from decentralized wastewater plant is considered and made a reliable alternate source in water resources management.

In semiarid region, using the effluent from decentralized wastewater plant in irrigation can effectively participate in reducing the gap between water supply and demand. In the future, there is a need to further studies, to examine the organic compound and toxic materials in decentralized wastewater plant; in addition, it is important to take more samples in order to study the change in the chemical properties of water, irrigated soil and plant.

Acknowledgements Many thanks to Sustainable Management of Available Water Resources with Innovation Technology (SMART). UFZ-HELMOHOLTZ Center for environmental research, Federal Ministry of Education and Research; without their support in the sample collection, the work would have not been done. In addition, the authors would thank Dr. Borbala Biro at Department of Soil Science and Water Management, Szent István University, Budapest, Hungary, for reviewing the paper.

Author contributions The conceptualization, methodology, writingoriginal draft, supervision and project administration were performed by MAH, and writing - original draft, conceptualization, writing editing, formal analysis were performed by NAH. All authors read and approved the final manuscript.

Funding The author(s) received no specific funding for this work.

Data availability The authors confirm that all data supporting the findings of this study are available from the corresponding author by request.

\section{Declarations}

Conflict of interest The authors have no conflicts of interest to declare that are relevant to the content of this article.

Open Access This article is licensed under a Creative Commons Attribution 4.0 International License, which permits use, sharing, adaptation, distribution and reproduction in any medium or format, as long as you give appropriate credit to the original author(s) and the source, provide a link to the Creative Commons licence, and indicate if changes were made. The images or other third party material in this article are included in the article's Creative Commons licence, unless indicated otherwise in a credit line to the material. If material is not included in the article's Creative Commons licence and your intended use is not permitted by statutory regulation or exceeds the permitted use, you will need to obtain permission directly from the copyright holder. To view a copy of this licence, visit http://creativecommons.org/licenses/by/4.0/.

\section{References}

Al-Hadidi M, Al-Kharabsheh A (2015) Effect of overpumping on water quality deterioration in arid areas a case study of dead sea Basin/ Jordan. Jordan J Agric Sci. https://doi.org/10.12816/0030074

Al-Hamaiedeh H, Bino M (2010) Effect of treated grey water reuse in irrigation on soil and plants. Desalination 256(1-3):315-321

Al-Khashman OA, Al-Hwaiti M, Al-Khatib L, Fraige F (2013) Assessment and evaluation of treated municipal wastewater quality for irrigation purposes. Res J Environ Earth Sci 5(5):229-236

Alobaidy AHMJ, Al-Sameraiy MA, Kadhem AJ, Majeed AA (2010) Evaluation of treated municipal wastewater quality for irrigation. J Environ Prot 1(03):216

APHA, Rice EW, Baird RB, Eaton AD, WWA, WEF (2017) Standard methods for examination of water and wastewater, 23st Edition, American Public Health Association, Washington, D.C

Asano T, Pettygrove GS (1987) Using reclaimed municipal wastewater for irrigation. Cal Agric 41:15-8

Ayers JE, Tanji KK (1999) Effect of drainage on water quality in arid and semiarid lands. In: Skaggs RW, van Schilfgaarde J (eds) Agricultural drainage. ASA-CSSA-SSSA, Madison, pp 831-867

Ayers RS, Westcot DW (1985) Water quality for agriculture. FAO Irrigation and drainage paper 29 Rev. 1. Food and Agricultural Organization, Rome

Bauder TA, Waskom RM, Davi JG (2010) Irrigation water quality criteria

Bhuriya V, and Dev P (2014) Groundwater quality evaluation for agriculture/irrigation of Meghnagar area, Jhabua Region, Madhya Pradesh, India. Asian J Multidiscip Stud 2(0). ISSN: 2321-8819 (Online)

Bouwer H, Idelovitch E (1987) Quality requirements for irrigation with sewage water. J. Irrig Drain Eng 113(4):516-535

Brtalik K, Feraud M, Huniu K, Jennings D, Howard K, Travis G (2012) Assessing decentralized wastewater treatment option in Santa Babara County. University of California

Capodaglio AG (2017) Integrated, decentralized wastewater management for resource recovery in rural and Peri-urban areas. Resources 6(2):22. https://doi.org/10.3390/resources6020022

Collins R, Jenkins A (1996) The impact of agricultural land use on stream chemistry in the middle Hills of the Himalayas, Napal. J Hydrol 185:71-86

Eaton FM (1950) Significance of carbonates in irrigated waters. Soil Sci 69(2):127-128

Fipps G (1998) Irrigation water quality standards and salinity management, The Texas a \& University system. http://www.extension. org/mediawiki/files/1/1e/Salinitydocument.pdf.

Halliwell J, Barlow KM, Nash DM (2001) A review of the effects of wastewater sodium on soil physical properties and their implications for irrigation systems. Aust J Soil Res 39(6):1259-1267

Hussain G, Al-Saati AJ (1999) Wastewater quality and its reuse in agriculture in Saudi Arabia. Desalination 123:241-251

Hussain MI, Muscolo A, Farooq M, Ahmad W (2019) Sustainable use and management of non-conventional water resources for rehabilitation of marginal lands in arid and semiarid environments. Agric Water Manag 221:462-476

Jajac N, Marović I, Rogulj K, Kilic J (2019) Decision support concept to selection of wastewater treatment plant location-the case study of town of Kutina. Croatia Water 11:1-16. https://doi.org/10.3390/ w11040717 
Jaramillo MF, Restrepo I (2017) Wastewater reuse in agriculture: a review about its limitations and benefits. Sustainability 9(10):1734. https://doi.org/10.3390/su9101734

Karanth KR (1987) Ground water assessment, development and management. McGraw Hill, New Delhi, p 720

Karanth KR (1989) Hydrogeology. McGraw-Hill, New Delhi

Khodapanah L, Sulaiman WNA, Khodapanah N (2009) Groundwater quality assessment for different purposes in Eshtehard District, Tehran Iran. Eur J Sci Res 36(4):543-553

Ministry of Industry and Commerce (2014) Jordan Institution for standards and metrology: irrigation water quality guidelines JS 1766:2014. 1st Edition

Ministry of Water and Irrigation (MWI) (2008) National water master plan of Jordan-water resources in Jordan. National water master plan directorate of MWI, Amman-Jordan, p 200

Ministry of Water and Irrigation (MWI) (2017) Jordan water sector facts and figures. Ministry of water and irrigation, Amman, Jordan

Ministry of Water and Irrigation (MWI) (2019). Water information system hydrological, geological and hydrogeological data bank. MWI Water Resources and Planning Directorate, Amman, Jordan

Maaß O, Grundmann P (2018) Governing Transactions and Interdependences between linked value Chains in a circular economy: the case of wastewater reuse in Braunschweig (Germany). Sustainability 10:1125

National Small Flows Clearinghouse at West Virginia University (2000) Decentralized wastewater treatment systems. Pipeline 11(4): $1-10$

Paliwal KV (1972) Irrigation with saline water, Z. Monogram No. 2 new series. IARI, New Delhi, p 198

Prasanth SV, Magesh NS, Jitheshlal KV, Chandrasekar N, Gangadhar K (2012) Evaluation of groundwater quality and its suitability for drinking and agricultural use in the coastal stretch of Alappuzha District, Kerala India. Appl Water Sci 2(3):165-175

Rengasamy P, North S, Smith A (2010). Diagnosis and management of sodicity and salinity in soil and water in the Murray irrigation region

Richards LA (1954) Diagnosis and improvement of saline alkali soils: agriculture, handbook, vol 160. US Department of Agriculture, Washington DC, p 60

Saidan MN, Al-Addous M, Al-Weshah RA, Obada I, Alkasrawi M, Barbana N (2020) Wastewater reclamation in major Jordanian industries: a viable component of a circular economy. Water 12:1276. https://doi.org/10.3390/w12051276
Shakir E, Zahraw Z, Al-Obaidy AHM (2017) Environmental and health risks associated with reuse of wastewater for irrigation. Egypt J Pet 26(1):95-102

Sharma A, Chong MN, Schouten P, Cook S, Ho A, Gardner T, Carlin G (2012) Decentralized wastewater treatment systems: system monitoring and validation. Urban Water Security Research Alliance Technical Report. p. 70

Subramani T, Elango L, Damodarasamy S (2005) Groundwater quality and its suitability for drinking and agricultural use in Chithar river basin, Tamil Nadu India. Envir Geol 47:1099-1110

Szabolcs, I and Darab, C. (1964). Influence of irrigation water of high sodium carbonate content of soils. In: Proceedings of the 8th international congress of ISSS, pp. 803-812, Tsukuba, Japan

Todd D (1995) Ground water hydrology, 3rd edn. Wiley, Hoboken

Todd D (1980) Groundwater, 2nd edn. Wiley, New York, p 535

UCCC (University of California Committee of Consultants) (1974) Guidelines for Interpretations of water quality for irrigation. Technical Bulletin, University of California Committee of Consultants, California, pp 20-2821

Ungureanu N, Vladut V, Voicu G (2020) Water scarcity and wastewater reuse in crop irrigation. Sustainability 12:9055. https://doi.org/10. 3390/su12219055

US Salinity Laboratory (1954) Diagnosis and improvement of Saline and Alkaline Soils, Department of Agriculture, Handbook No. 60 , p. 160

Van Hoorn J, Van Alpen JG (1990) Salinity control, salt balance and leaching requirement of irrigated soil-9. International Course of Land Drainage, Wageningen

Water Authority of Jordan (WAJ) (2008) Water authority of Jordan files (WAJ Files), Amman- Jordan

WHO (2005) A regional overview of wastewater management and reuse in the Eastern Mediterranean Region, World health organization, Regional office for the Eastern Mediterranean Regional, California Environmental Health Association

Wilcox LV (1948) The quality of water for irrigation use (No. 170282). United States department of agriculture, Economic Research Service

Publisher's Note Springer Nature remains neutral with regard to jurisdictional claims in published maps and institutional affiliations. 